\title{
Dating diamonds using the Re-Os isotope technique: A study of sulfide inclusions in Siberian diamonds
}

D.G. Pearson', Shirey, S.B. ${ }^{2}$, G.P. Bulanova ${ }^{3}$, Carlson, R.W. ${ }^{2}$ and Milledge, H.J. ${ }^{4}$

1 Department of Geological Sciences, Durham University, South Rd, Durham, DH1 3LE, U.K.

2. Department of Terrestrial Magnetism, Carnegie Institution of Washington, 5241 Broad Branch Rd, N.W. Washington, DC 20015, U.S.A.

3 TsNiGRI, 129B Varshavsky sh. Moscow, Russia.

4 Department of Geological Sciences, University College London, Gower Street, London, UK

\section{Introduction}

Knowledge of diamond crystallisation ages, their relationship to the host kimberlite, and the lithosphere that they are erupted through also has important implications for diamond exploration. However, because of technical difficulties, the crystallisation ages of different suites of diamonds is one of the least well known aspects of diamond geology. Sm-Nd model and isochron ages of silicate inclusions have been obtained for various suites of diamonds (e.g., Richardson et al, 1984; 1993). Because of the low Nd contents of silicate inclusions this approach necessitates the compositing of inclusions from many different diamonds that may not be co-genetic. Furthermore, documentation of zonation within silicate inclusions in diamonds suggest the possibility of very young ages for some diamonds (Shimizu and Sobolev, 1995). We have sought to obtain ages from single sulfide inclusions within diamonds by utilising the Re-Os isotope technique.

\section{Samples and analytical methods}

Sulfide inclusions, exposed during polishing of diamond "plates" cut from whole stones were selected for analyses. Where plates contained multiple inclusions they were laser cut to obtain fragments with single inclusions. This allows the possibility of obtaining ages from individual sulfide inclusions from different growth zones of the diamonds (Pearson et al, submitted) and even isochrons from single diamonds (Pearson et al, in press). Many of the inclusions studied have been previously characterised for major and trace elements (Bulanova et al, 1996). The attraction of the technique is that the Os from single sulfide and eclogite paragenesis diamonds can be distilled using a microdistillation technique that yields procedural blanks of $5 \mathrm{fg}\left(5^{*} 10^{-15} \mathrm{~g}\right)$. Such blanks, combined with the high ionisation efficiencey of N-TIMS permit isotope ratios to be measured to better than $1 \%$ precision on less than $1 \mathrm{pg}$ of Os. Re is then separated on micro-anion cols (blank c. $100 \mathrm{fg}$ ), or run directly on an Elan 6000 ICP-MS using direct injection nebulisation (blank $50 \mathrm{fg}$ ). If a mixed PGE spike is added before distillation, isotope dilution data for Pt, Ir Pd and Ru can also be determined by ICP-MS on the same sulfide grain. The host diamond plates for each sulfide analysed are examined for internal structure using cathodoluminescence, and their $\mathrm{N}$-content and aggregation state is 
measured using FTIR spectroscopy to try to relate the radiometric inclusion ages to aggregation information in order to better understand the information gained from aggregation studies.

\section{Results}

Sulfide inclusions in diamond have been broadly related paragenetically to silicate inclusions in diamonds based on their Ni content. Those relating to the eclogite paragenesis (E-type inclusions), have less than c. $16 \mathrm{wt} \% \mathrm{Ni}$ while those corresponding to a peridotitic (P-type) paragenesis have higher Ni contents (Yefimova et al, 1983; Bulanova et al, 1996). This system may not be universally applicable as there appears to be a compositional continuum fromlow-Ni to high-Ni sulfides (Bulanova et al, 1996; Deines and Harris, 1995) and Ni-rich pentlandites can befound in websterite xenoliths (Pearson et al, in press). However, a combination of sulfide PGE and Ni contents does appear to be a powerful paragenetic discriminant (Bulanova et al, 1990; Pearson et al, in press). Ptype sulfides have high Os content, from c 1 to over $20 \mathrm{ppm}$. In contrast, E-type sulfides have low Os, less than 1 ppm. 6 E-type sulfides from the Koffiefontein pipe, S. Africa have Os contents from 5 to $122 \mathrm{ppb}$ whereas the range is somewhat larger for Siberian E-type sulfides ( 3 tp $748 \mathrm{ppb}$, with samples from Mir showing the largest range. Re/Os of the two paragenetic groups mirror that seen in xenolith suites, i.e., E-type sulfides have higher Re/Os than P-type sulfides, consistent with their differing origins. This difference is Re/Os is refelcted in the measured Os isotopic ratios, with E-type sulfides being generally substantially more radiogenic than P-types. E-type ${ }^{187}$ Os/ ${ }^{188}$ Os range from 0.120 to 0.694 whereas P-type sulfides range from very unradiogenic values, 0.1056 , characteristic of ancient Re-depletion, and similar to the least radiogenic Siberian xenolith measurements (Pearson et al, 1995), to values close to present-day convecting mantle (0.1270). One P-type sample from Aikhal has an unusually radiogenic ${ }^{187} \mathrm{Os} /{ }^{188}$ Os of 0.2255.

\section{Diamond formation ages}

The most unradiogenic ${ }^{187} \mathrm{Os} /{ }^{188} \mathrm{Os}$ for P-type inclusions from Udachnaya (inclusing a sample with 3 separate inclusions, plus another diamond sulfide) are supported by low Re contents, giving Re-Os model ages of between $3.1 \pm 0.3$ and $3.5 \pm 0.3 \mathrm{Ga}$ and suggesting very ancient crystallisation ages, as indicated by insitu $\mathrm{Pb}$-isotope measurements (Rudnick et al, 1993). These ages are in close agreement with the Sm-Nd model ages obtained for P-type diamond composites from Finsch and Kimberley, S. Africa (Richardson et al, 1984) but in marked contrast to the young crystallisation age suggested by a Re-Os isochron and model ages for 2 sulfides from a P-type diamond from Koffiefontein, S. Africa (Pearson et al, in press). Re data are not presently available for the E-type Siberian sulfides and so we cannot yet constrain their age. A suite of E-type sulfides from Koffiefontein, S. Africa have Proterozoic madel and isochron ages.

When evaluating the P-type sulfide Re-Os ages it is important to consider to what extent their ancient model ages could be a product of recent sulfide (and diamond) crystallisation inheriting more ancient isotopic systematics, for instance due to re-mobilisation of ancient lithospheric sulfides. The current data base does not support this possibility. The likelyhood of 3 different sulfides within the same diamond inheriting ancient Os isotope signatures that are supported by the 
measured Re/Os is not strong (Pearson et al, submitted). Furthermore, the high degree of measured $\mathrm{N}$-aggregation of the host diamond to these sulfides produce data which lie on smooth isotherms at reasonable mantle temperatures for a $3 \mathrm{Ga}$ mantle residence time. This, combined with an additional P-type sulfide inclusion from the same mine, Udachnaya, giving a model age within the small spread of ages defined by the inclusions in sample 3648 further mitigate against inheritance as an explanation for the ancient model ages. Thus, we beleive that the two P-type Siberian diamonds crystallised in the mid-Archaean. With further analyses of Siberian diamonds we hope to determine the overall timing of P- and E-type diamond formation in the Siberian lithosphere, and compare this with Kaapvaal diamond formations ages which current indicate diamond crystallisation over a range of geological time (Pearson et al, in press). The potential of the single-crystal Re-Os dating technique to obtain isochrons for single diamonds makes it extremely powerful in diamond geochronology.

\section{References}

Bulanova, G.P., Griffin, W.L., Ryan, C.G., Shestakova, O.Ye, and Barnes, S-J., 1996, Trace elements in sulfide inclusions from Yakutian diamonds: Contrib. Mineral. Petrol. 124, p111-125.

Deines, P. and Harris, J. W., 1995, Sulfide inclusion chemistry and carbon isotopes of African diamonds: Geochim Cosmochim. Acta 59, p. 3173-3188.

Pearson D. G., Shirey S. B., Carlson R. W., Boyd F. R., Pokhilenko N. P., and N.Shimizu, 1995b, Re-Os, Sm-Nd \& Rb-Sr isotope evidence for thick Archaean lithospheric mantle beneath the Siberia craton modified by multi-stage metasomatism. Geochim. Cosmochim. Acta 59, 959-977.

Pearson, D.G., Shirey, S.B., Harris, J.W., \& Carlson, R.W., in press, Constraining diamond crystallisation ages: A Re-Os isotopic study of sulfide diamond inclusions from the Koffiefontein kimberlite, S. Africa: Earth Planet. Sci. Lett.

Pearson, D.G., Shirey, S.B., Bulanova, G.P., \& Carlson, R.W. and Milledge, H.J., submitted, Single crystal Re-Os isotope study of sulfide inclusions from a Siberian diamond: Geochim. Cosmochim. Acta.

Richardson S. H., Gurney J. J., Erlank A. J., and Harris J. W., 1984, The origin of diamonds in old enriched mantle: Nature, 310, p. 198-202.

Richardson S. H., Harris J. W., and Gurney J. J. (1993) Three generations of diamonds from old continental mantle: Nature, 366, p. 256-258.

Rudnick, R. L., Eldridge, C. S., and Bulanova, G. P., 1993, Diamond growth history from in situ measurement of Pb and $\mathrm{S}$ isotopic compositions of sulfide inclusions: Geology, 21, p. 13-16.

N. Shimizu, N and Sobolev, N.V., 1995, Young peridotitic diamonds from the Mir kimberlite pipe: Nature, 375, p. 394-397.

Yefimova E. S., Sobolev N. V., and Pospelova L. N., 1983, Sulfide inclusions in diamond and specific features of their paragenesis. Zap. Vsesoy. Mineral. Obsh.: 112, p.300-310. 